\title{
EVALUASI KESESUAIAN LAHAN KECAMATAN TOMPOBULU KABUPATEN BANTAENG UNTUK PENGEMBANGAN TANAMAN LADA (Piper nigrum L)
}

\author{
Land Evaluation in Tompobulu Subdistrict, Bantaeng Regency for Development of Pepper \\ Plant (Piper nigrum L)
}

\author{
* Muhammad Iqbal, ${ }^{* *}$ Hazairin Zubair, ${ }^{* *}$ Rismaneswati \\ *Alumni Jurusan Ilmu Tanah, Fakultas Pertanian, Universitas Hasanuddin, Makassar \\ *** Jurusan Ilmu Tanah, Fakultas Pertanian, Universitas Hasanuddin, Makassar \\ (corresponding email: amuhammadiqbal14@gmail.com)
}

\begin{abstract}
Potential land resources can be expected through land evaluation activities. This study aims to evaluate the suitability of Tompobulu Subdistrict of Bantaeng Regency for the development of pepper plant (Piper nigrum L). This research was conducted in Tompobulu Sub-district of Bantaeng Regency which started from March to July 2016. This research used qualitative method and to determine land suitability using simple limiting factor approach. Determination of observation points based on the overlapping results of the baseline maps that resulted in 6 units of observation (soil profile). Production data and management of pepper crop obtained from farmers of respondents amounted to 10 people. The result of the study shows that the climate type of the research area according to Oldeman is classified as B2 with the actual land suitability class which is quite suitable (S2) with 3,657 $\mathrm{Ha}$ and the marginal fit (S3) with 3,023 Ha with rainfall limiting factor, soil depth, Slope, and surface rocks whereas the suitability class is quite suitable (S2) with an area of 6,160 $\mathrm{Ha}$ and corresponding marginally (S3) with an area of $520 \mathrm{Ha}$ with rainfall and soil depth limiting factors. The potential of pepper plant development in Tompobulu Sub-district of Bantaeng Regency is quite large indicated by the
\end{abstract}

percentage of land area that is quite suitable (S2) $(82.40 \%)$.

Keywords: Land evaluation, pepper, Tompobulu

\section{PENDAHULUAN}

Lada (Piper nigrum L) merupakan komoditas ekspor potensial dan komoditas andalan ekspor tradisional bagi Indonesia, merupakan produk tertua dan terpenting yang diperdagangkan di dunia (Wahid dan Suparman 1986). Pada tahun 2005 produksi lada Indonesia menduduki urutan kedua dunia setelah Vietnam. Lada menyumbang devisa negara terbesar keempat untuk komoditas perkebunan setelah minyak sawit, karet, dan kopi.Berdasarkan data dari International Pepper Community (IPC), ekspor lada nasional mencapai 41.500 ton, pada 2013. Jumlah ekspor turun hingga $33,71 \%$ dibandingkan dengan tahun 2012 mencapai 62.608 ton.

Kesesuaian lahan untuk tanaman lada dapat diketahui melalui beberapa pendekatan atau metode penilaian kelas kesesuain lahan seperti metode parametrik yang merupakan salah satu diantaranya. Pendekatan ini berdasarkan atas nilai indeks lahan dan faktor-faktor pembatas sehingga penilaian data mendekati detail serta 
memungkinkan penilain yang bersifat subjektif dapat dihindari.

Kecamatan Tompobulu Kabupaten Bantaeng merupakan salah satu daerah penghasil tanaman perkebunan khususnya tanaman lada. Data produksi pada tahun 2009-2011 sebanyak 11 ton/tahun. Produksi lada dianggap kecil bila dibandingkan dengan luas lahan yang digunakan sebesar $76 \mathrm{Ha}$ (BPS ProvinsiSulawesi Selatan, 2012).

Untuk mengoptimalkan produksi Lada di Kecamatan Tompobuluperlu dilakukan evaluasi kesesuaian lahan yang disesuaikan penggunaan dan pengelolaannya. Tujuan tersebut dapat ditingkatkan apabila dilakukan dengan arahan teknis lahan yang tepat, sehingga penggunaan lahan dapat dimanfaatkan dengan mempertimbangkan potensi yang masing-masing dimiliki oleh setiap lahan. Kondisi tersebut harus menjadi kajian, riset, dan penelitian bagaimana tingkat kesesuaian lahan tanaman lada di Kecamatan Tompobulu Kabupaten Bantaeng. Oleh sebab itu dilakukan penelitian evaluasi kesesuaian lahan di Kecamatan Tompobulu Kabupaten Bantaeng Untuk Pengembangan Tanaman Lada (Piper nigrum L).

\section{METODOLOGI PENELITIAN}

Penelitian ini dilaksanakan di Kecamatan Tompobulu, Kabupaten Bantaeng. Analisis contoh tanah dilaksanakan di Laboratorium Kimia Tanah Jurusan Ilmu Tanah Fakultas Pertanian Universitas Hasanuddin, Makassar, Penelitian ini diperkirakanakan berlangsung dari bulan Januari2016 sampai Juni 2016.

Alat yang digunakan dalam penelitian ini meliputi: peralatan dasar survey tanah (Ring sampel, meteran, meteran profil, cangkul, GPS (Global Positioning System), kompas, Munsel soil colour chart, DIP (Daftar Isian Profil), seperangkat computer dengan program Ms. Office 2007 dan Arc Gis untuk analisis data. Bahan-bahan yang digunakan dalam penelitian ini yaitu: Peta Rupa BumiIndonesia skala 1 : 50.000 (Bakosuraltanal, 1991. Lembar 201062),Peta Penggunaan Lahan skala 1 : 50.000 (peta penutupan lahan Sulawesi selatan,2009), Peta Administrasi skala 1 : 50.000 (BPS, 2010), Peta Kelerengan skala 1 : 50.000 (hasil analisis SRTM30), Peta Sitem Lahan skala 1 : 250.000 (Reppprot, 1989), Data curah hujan 2007-2015 (BMKG, 2016), kelembaban relatif, temperatur, dan suhu 2004-2011 (BMKG Wilayah IV Makassar).

Ada tiga tahap penting dalam metode penelitian ini yaitu Studi Pustaka, Survei Lapangan dan Analisis Sifat Tanah.

\section{Studi Pustaka}

Studi pustaka berfungsi untuk mengumpulkan informasi serta data-data yang dibutuhkan. Data-data tersebut berupa data curah hujan Tompobulu 9 tahun terakhir, peta geologi, peta jenis tanah, peta penggunaan lahan, peta lereng, peta rupa bumi Indonesia, peta batas adaministrasi serta peta topografi. Peta-peta tersebut dapat digunakan untuk memperoleh informasi tentang kondisi lokasi.

\section{Penentuan Satuan Lahan}

Satuan lahan merupakan hasil overlay beberapa peta dasar yaitu peta lereng, peta administrasi, peta penggunaan lahan, peta geologi dan menghasilkan 5 unit lahan sebagai data sekunder. Penentuan pengambilan titik sampel didasarkan atas unit lahan yang ada dengan memperhitungkan luasan tiap unit lahan sehingga satu unit lahan dengan luasan yang besar diambil lebih dari satu sampel, sebagaimana ditunjukan pada Gambar 1.

Maksud dari survei lapangan adalah untuk mengamati profil tanah dan pengambilan sampel dengan metode pemilihan lokasi dalam penelitian ini adalah 
purposive sampling yaitu pengambilan sampel berdasarkan pertimbangan kondisi atau syarat tertentu sedangkan Metode matching atau pembandingan nilai kelas kesesuaian lahan didasarkan pada nilai terendah sebagai faktor pembatas evaluasi kesesuaian lahan.

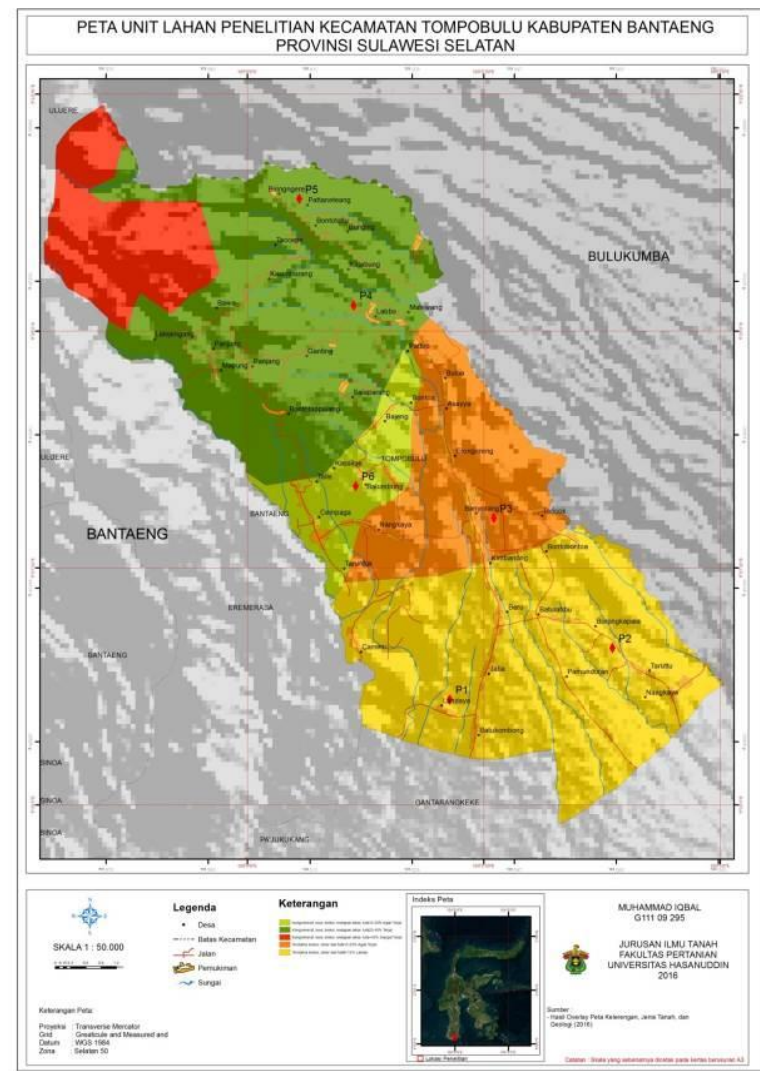

Gambar 1. Peta unit lahan dan titik pengambilan sampel.

\section{Analisis Sampel Tanah di Laboratorium}

Analisis tanah berfungsi untuk mengetahui sifat-sifat fisik dan kimia tanah sehingga dapat diketahui pengaruh topografi terhadap perubahan sifat-sifat tanah, adapun sifat tanah yang dianalisis yaitu: Pemisahan fraksi tanah digunakan metode Hydrometer, penentuan C-Organik dengan metode walkey and black, $\mathrm{pH}$ tanah, penentuan KTK dengan ekstrak ammonium asetat, kejenuhan basa.
Adapun tahapan penelitian dapat dilihat pada Gambar 2.

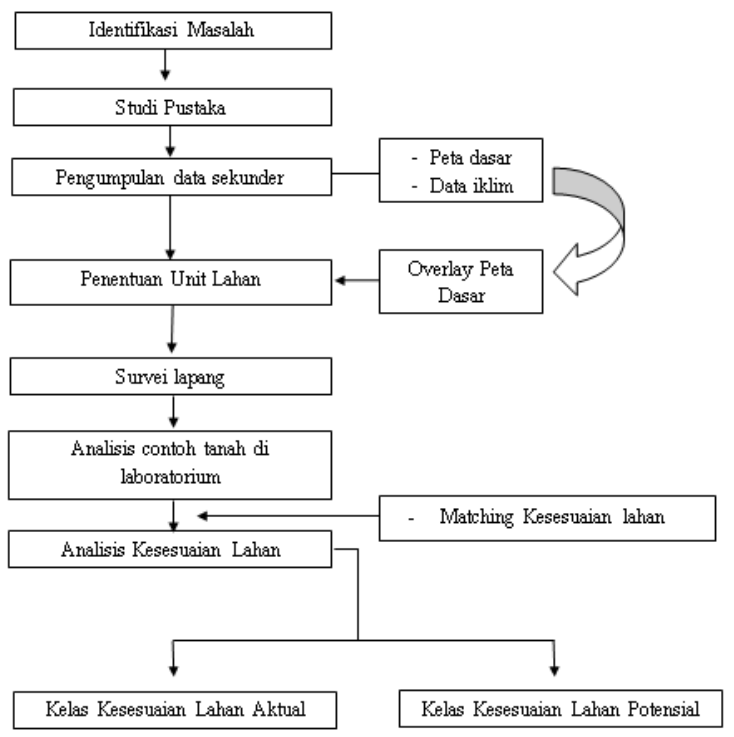

Gambar 2. Tahapan Penelitian

\section{KEADAAN UMUM LOKASI}

Kecamatan Tompobulu merupakan salah satu Kecamatan yang terdapat di Kabupaten Bantaeng. Secara astronomis terletak antara $05^{\circ} 27^{\prime} 08^{\prime \prime}$ LS dan $120^{\circ} 02^{\prime} 26^{\prime \prime}$ BT. Secara geografis Luas wilayah Kecamatan Tompobulu adalah 7476 Ha. Kecamatan Tompobulu dengan keadaan wilayahnya terdiri dari perbukitan mempunyai jarak tempuh $+20 \mathrm{~km}$ dari Ibukota Kecamatan ke Ibukota Kabupaten. Kecamatan Tompobulu terdiri dari 10 Kelurahan yang meliputi Kelurahan Pattaneteang (1.304 Ha), Kelurahan Labbo (1.583 Ha), Kelurahan Bonto Tappalang (525 Ha), Kelurahan Balumbung (379 Ha), Kelurahan Erengereng (477 Ha), Kelurahan Campaga (447 $\mathrm{Ha})$, Kelurahan Banyorang (502 Ha), Kelurahan Lembang Gantarang Keke (719 $\mathrm{Ha})$, Kelurahan Patalassang $(1.178 \mathrm{Ha})$ dan Kelurahan Bonto Bontoa (362 Ha). Peta administrasi Kecamatan Tompobulu dapat dilihat pada Gambar 3. 


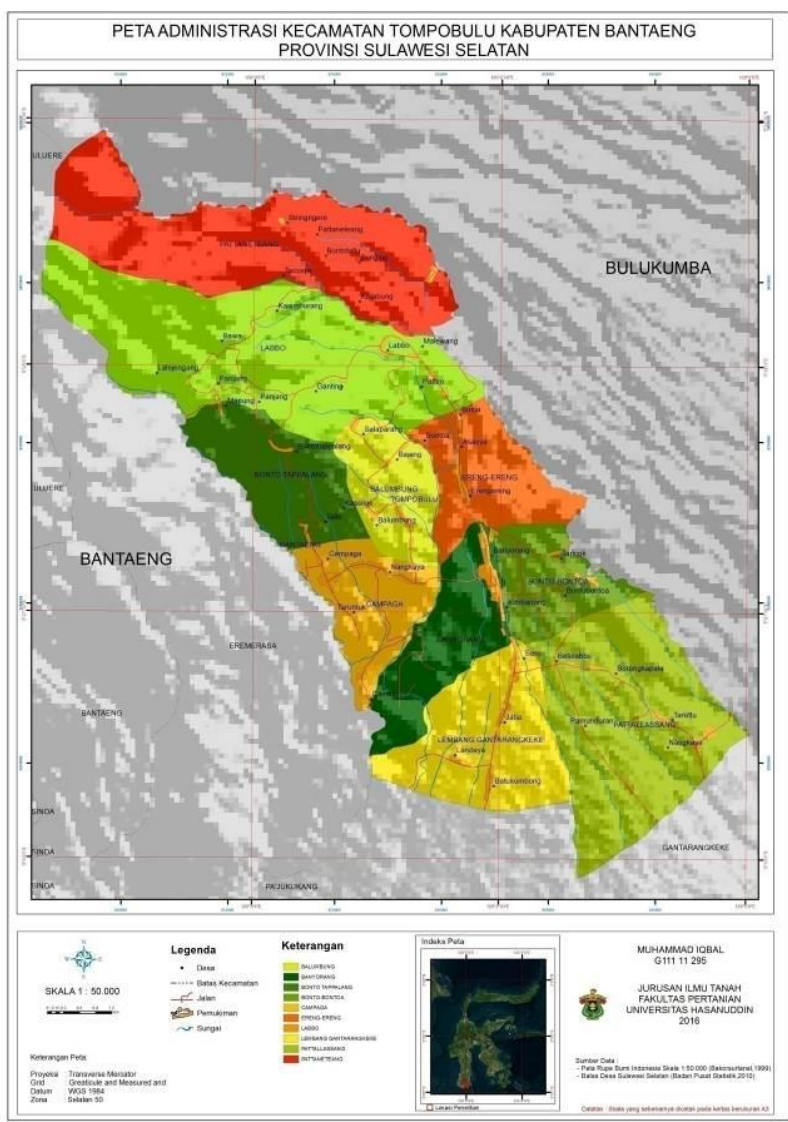

Gambar 3. Peta Administrasi Kecamatan Tompobulu Kabupaten Bantaeng Provinsi Sulawesi Selatan.

Berdasarkan hasil interpretasi pada peta rupa bumi skala $1: 50.000$ (sumber peta digital RBI Bakosurtanal, 1999), maka keadaan topografi pada daerah penelitian ini pada umumnya mempunyai bentuk wilayah berbukit dan bergelombang dengan lereng yang landai hingga sangat terjal. Bentuk wilayah dan kemiringan lereng disajikan pada Tabel 1 dan peta kelas lereng ditampilkan pada Gambar 4.
Tabel 1. Bentuk wilayah dan kemiringan lereng di Kecamatan Tompobulu

\begin{tabular}{cccc}
\hline \multirow{2}{*}{ Kelas Lereng } & $\begin{array}{c}\text { Selang } \\
\text { Lereng } \\
(\boldsymbol{\%})\end{array}$ & $\mathbf{( h a )}$ & $\mathbf{( \% )}$ \\
\cline { 3 - 4 } & $8-15$ & 2527 & 33.80 \\
Landai & $15-25$ & 1619 & 21.66 \\
Agak Terjal & $25-45$ & 2534 & 33.89 \\
Terjal & $>45$ & 796 & 10.65 \\
Sangat Terjal & & $\mathbf{7 4 7 6}$ & $\mathbf{1 0 0}$ \\
\hline Total & & &
\end{tabular}

Sumber: Hasil Analisis SRTM30

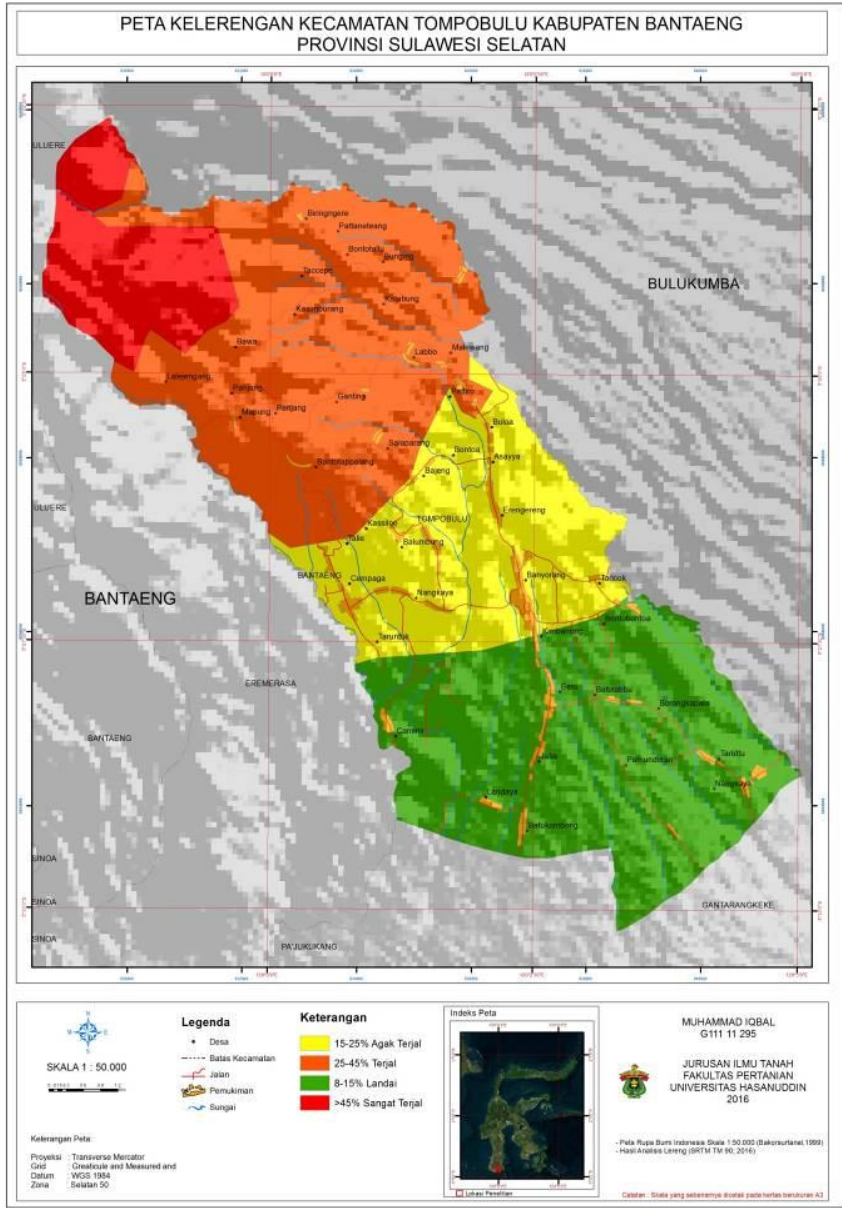

Gambar 4. Peta Kelerengan Kecamatan Tompobulu Kabupaten Bantaeng Provinsi Sulawesi Selatan. 
Berdasarkan Peta sistem lahan RePPProT (Bakosurtanal, 1989), jenis tanah yang terdapat pada daerah penelitian tergolong atas Inceptisols, Ultisols dan Alfisols. Jenis tanah disajikan pada Tabel 2 dan peta jenis tanah ditampilkan pada Gambar 5.

Tabel 2. Jenis tanah di kecamatan Tompobulu

\begin{tabular}{ccc}
\hline \multirow{2}{*}{ Jenis Tanah } & \multicolumn{2}{c}{ Luas } \\
\cline { 2 - 3 } & (ha) & $(\boldsymbol{\%})$ \\
\hline Inceptisols & $2.733,62$ & 36.57 \\
Ultisols & $4.239,81$ & 56.71 \\
Alfisols & 502,58 & 6.72 \\
\hline Total & $\mathbf{7 4 7 6}$ & $\mathbf{1 0 0}$ \\
\hline
\end{tabular}

Sumber: Peta sistem lahan RePPProT (Bakosurtanal, 1989)

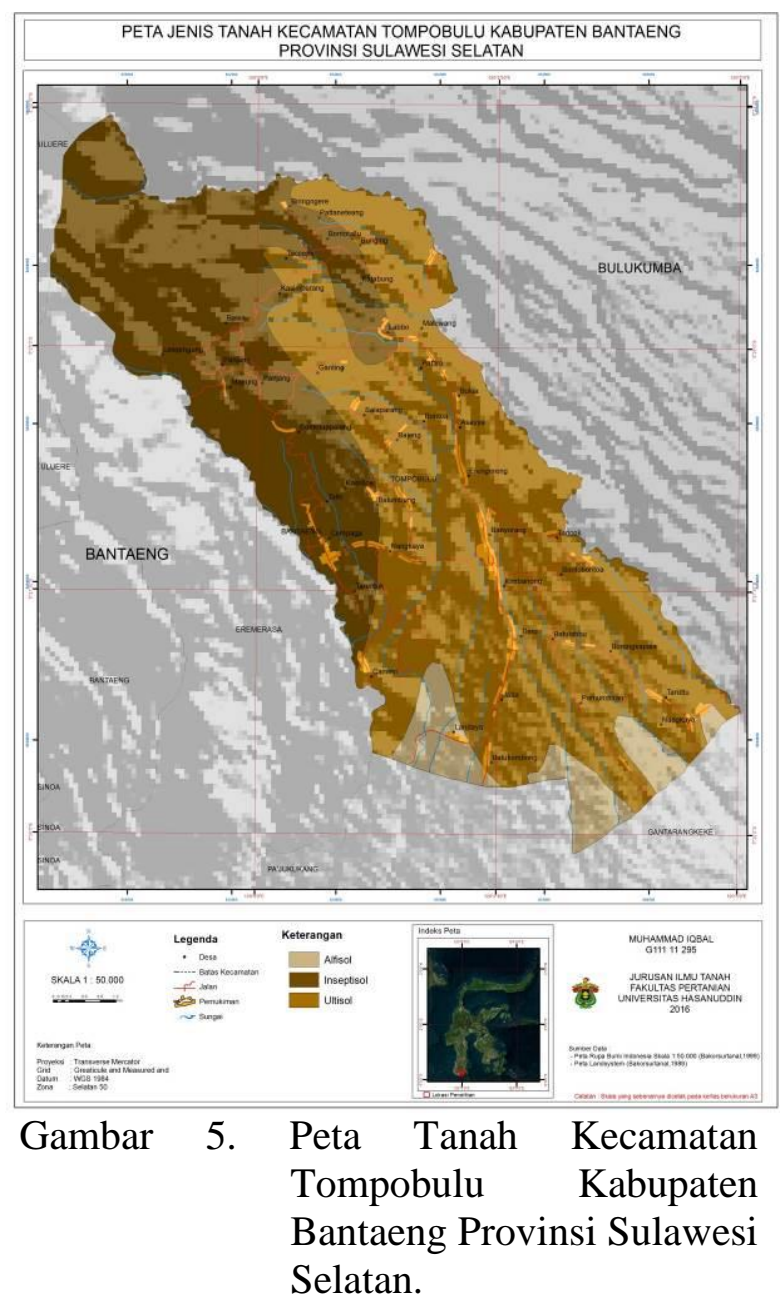

Berdasarkan peta penggunaan lahan kecamatan Tompobulu, maka penggunaan lahan yang terdapat pada lokasi penelitian terbagi atas pertanian lahan kering,Semak Belukar dan sawah. Jenis tata guna lahan dan masing-masing luasan disajikan pada Tabel 3 dan peta penggunaan lahan ditampilkan pada Gambar 6.

Tabel 3. Jenis tata guna lahan di Kecamatan Tompobulu

\begin{tabular}{crc}
\hline \multirow{2}{*}{ Jenis Tata guna lahan } & \multicolumn{2}{c}{ Luas } \\
\cline { 2 - 3 } & (ha) & $(\boldsymbol{\%})$ \\
\hline Hutan & 639 & 8.55 \\
Pertanian Lahan Kering & 2523 & 33.75 \\
Sawah & 219 & 2.94 \\
Semak / Belukar & 4095 & 54.76 \\
\hline Total & $\mathbf{7 4 7 6}$ & $\mathbf{1 0 0}$ \\
\hline
\end{tabular}

Sumber: Peta penutupan lahan Sulawesi Selatan, 2009

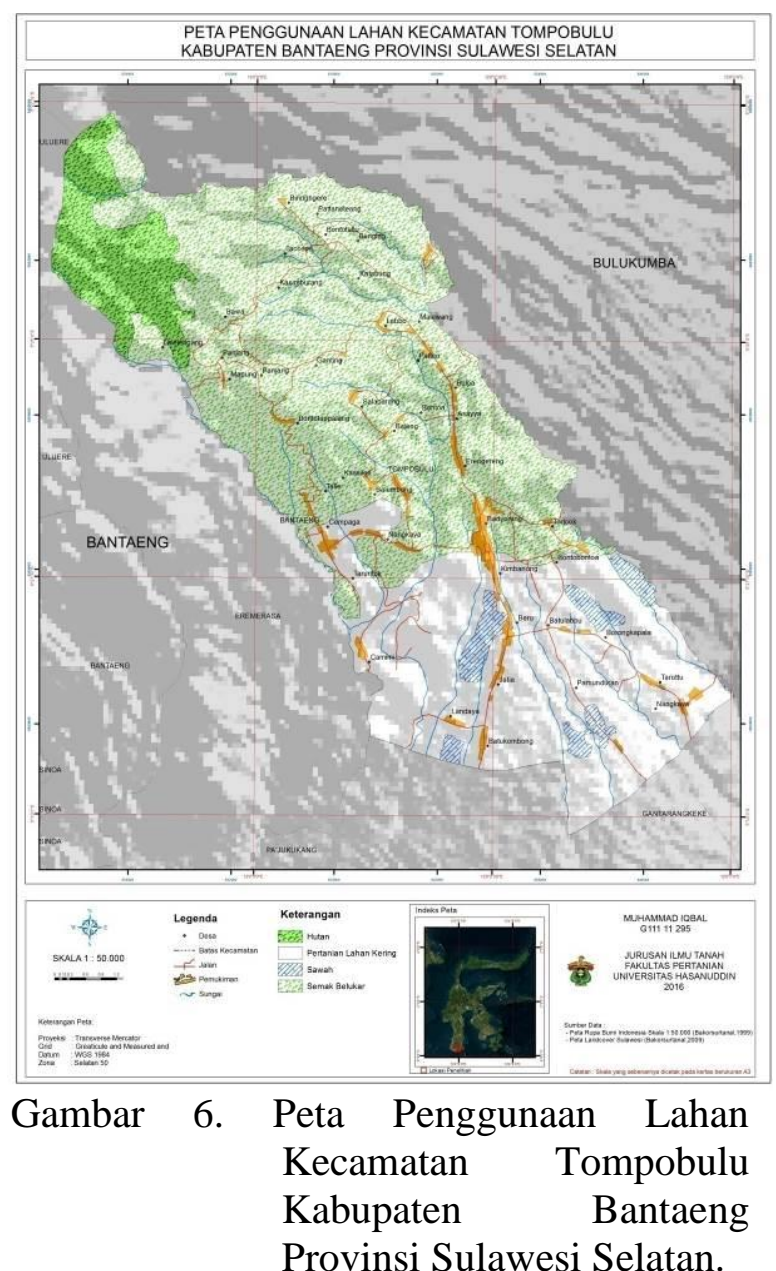


Berdasarkan peta geologi regional Sulawesi, kecamatan Tompobulu memiliki jenis batuan terbagi atas Formasi Batuan Gunungapi Lompobattang / Qlv (Konglomerat, lava, breksi, endapan lahar, tufa) dan Formasi Breksi, lahar dan Tufa/Qlvb (Terutama breksi, lahar dan tufa). Jenis batuan dan masing-masing luasan disajikan pada Tabel 4 dan peta penggunaan lahan ditampilkan pada Gambar 7.

Tabel 4. Formasi Batuan Kecamatan Tompobulu

\begin{tabular}{|c|c|c|}
\hline \multirow{2}{*}{ Formasi Batuan } & \multicolumn{2}{|c|}{ Luas } \\
\hline & (ha) & $(\%)$ \\
\hline $\begin{array}{c}\text { Formasi Batuan } \\
\text { Gunungapi } \\
\text { Lompobattang (Qlv) }\end{array}$ & 3819 & 51.08 \\
\hline $\begin{array}{l}\text { Formasi Breksi, lahar } \\
\text { dan Tufa (Qlvb) }\end{array}$ & 3657 & 48.92 \\
\hline Total & 7476 & 100 \\
\hline
\end{tabular}

Berdasarkan data curah hujan sembilan tahun terakhir (2007 samapi 2015) dari stasiun Tompobulu/Banyorang, maka klasifikasi iklim menurut Oldeman adalah tipe iklim B2 dengan jumlah 8 BB (Bulan Basah), 1 BL (bulan lembab) dan 3 BK (bulan kering). Adapun jumlah bulan basah dari masing-masing tipe utama dan jumlah bulan kering dari masing-masing subtipe dijelaskan pada Tabel 5 dan Tabel 6 .

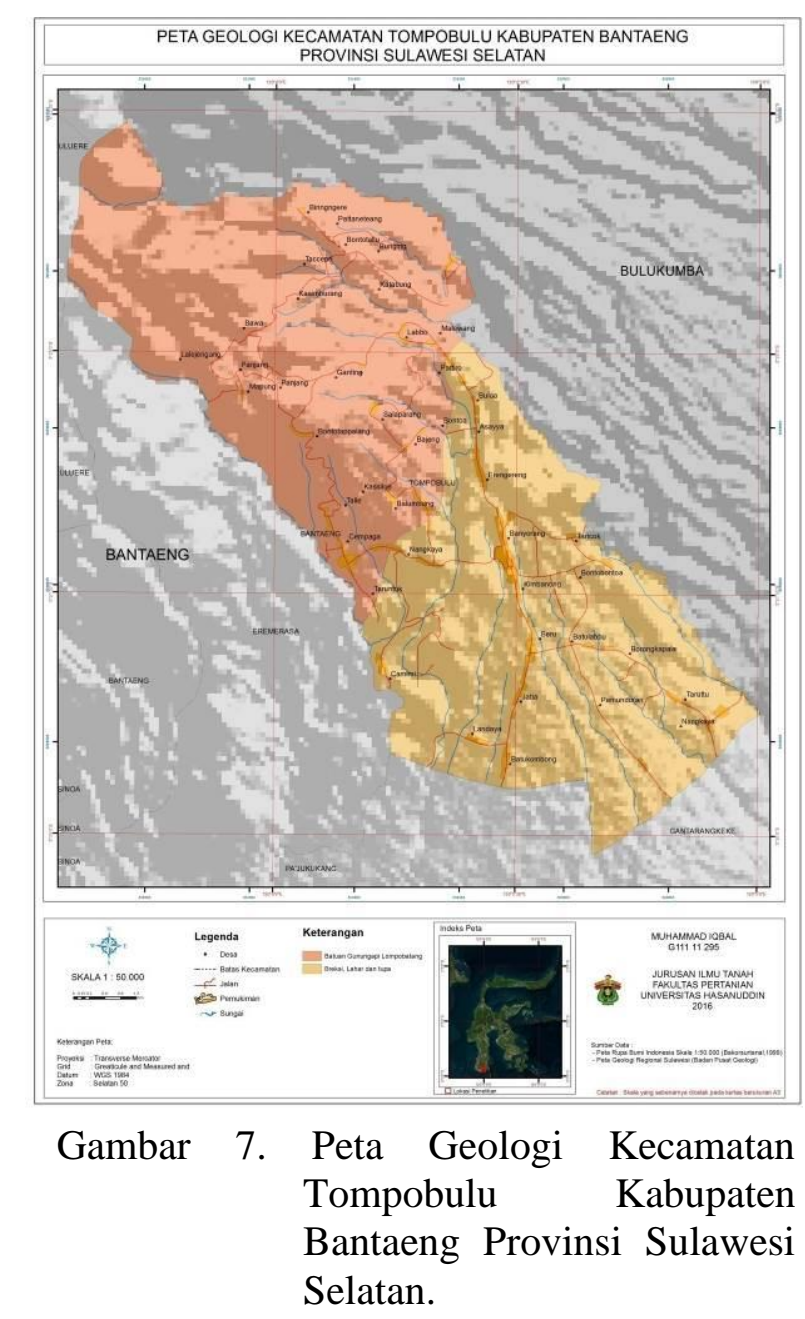

Tabel 1. Klasifikasi tipe iklim menurut oldeman

\begin{tabular}{cccc}
\hline $\begin{array}{c}\text { Tipe } \\
\text { Utama }\end{array}$ & $\begin{array}{c}\text { Jumlah BB } \\
\text { (bulan) }\end{array}$ & $\begin{array}{c}\text { Sub } \\
\text { Tipe }\end{array}$ & $\begin{array}{c}\text { Jumlah } \\
\text { BK (bulan) }\end{array}$ \\
\hline A & $>9$ & 1 & $<2$ \\
B & $7-9$ & 2 & $2-3$ \\
C & $5-6$ & 3 & $4-6$ \\
D & $3-4$ & 4 & $>6$ \\
E & $<3$ & & \\
\hline
\end{tabular}


Tabel 6. Data rata-rata curah hujan selama 9 tahun terakhir (2007-2015). penelitian dikelompokkan ke dalam tipe iklim B2. Data curah hujan selengkapnya dapat dilihat pada Lampiran.

\begin{tabular}{|c|c|}
\hline \multirow{2}{*}{ Bulan } & $\begin{array}{c}\text { Stasiun Curah Hujan } \\
\text { Tompobulu/Banyorang }\end{array}$ \\
\hline & $\begin{array}{c}\text { Rata - Rata Curah Hujan Bulanan } \\
(\mathrm{mm})\end{array}$ \\
\hline Januari & 382.56 \\
\hline Februari & 236 \\
\hline Maret & 271.76 \\
\hline April & 421.44 \\
\hline Mei & 515.67 \\
\hline Juni & 442 \\
\hline Juli & 242.56 \\
\hline Agustus & 63.44 \\
\hline September & 98.25 \\
\hline Oktober & 96 \\
\hline November & 173.89 \\
\hline Desember & 444.5 \\
\hline Total & 3388.08 \\
\hline $\begin{array}{c}\text { Rata - } \\
\text { rata }\end{array}$ & 282.34 \\
\hline BB & 8 \\
\hline BL & 1 \\
\hline BK & 3 \\
\hline $\begin{array}{l}\text { Tipe Iklim } \\
\text { (Oldeman) }\end{array}$ & B2 \\
\hline Sumber: $\mathrm{Su}$ & $\begin{array}{l}\text { Bidang Manajemen } \\
\text { ah IV Makassar }\end{array}$ \\
\hline
\end{tabular}

Suhu dan Kelembaban

Temperatur udara rata - rata pada Kabupaten Bantaeng berkisar $23^{\circ} \mathrm{C}$ sampai $29^{\circ} \mathrm{C}$. Dan kelembaban rata-rata berkisar 39 \% - 96 \%. Data suhu dan kelembaban selama 8 tahun terakhir (2004-2011) dapat dilihat pada lampiran.

\section{Karakteristik Tanah}

Hasil survey lapangan menunjukan lokasi lahan penelitian memiliki lereng landai hingga berbukit $(8-45 \%)$, $\mathrm{pH}$ tanah mulai dari masam sampai agak masam $(4,75$ 6,36), ktk antara 19,14 - 25,72 cmol/kg tanah, kejenuhan basa mulai dari 32,4 $49,44 \%$, tekstur liat sampai lempung liat berpasir. Data hasil analisis contoh tanah dilaboratorium pengamatan tanah dan medan selengkapnya ditunjukan pada Tabel 7.

\section{Unit Lahan 1}

Unit lahan1 terletak pada koordinat $120^{\circ} 2^{\prime}$ 8.33" BT dan $5^{\circ} 28^{\prime} 53.22 "$ LS di Desa Landaya pada ketinggian \pm 302 mdpl. Topografi berombak (8-15\%), vegetasi didominasi kakao, kopi, jati, dan pisang, ditemui adanya batuan diatas permukaan $<5 \%$, dan tidak terlihat adanya erosi maupun genangan.

Hasil analisis laboratorium menunjukan pada horison A memiliki tekstur lempung berdebu dengan kandungan pasir 24\%, debu $53 \%$ dan liat $23 \%$. Kandungan C-organik 2,67\%, pH 6,36, KTK $23,73 \mathrm{cmol} / \mathrm{kg}$ tanah dan KB 42,91\%. Horison B memiliki tekstur lempung berdebu dengan kandungan pasir 5\%, debu $71 \%$ dan liat $24 \%$. Kandungan C-organik $3,5 \%, \mathrm{pH} 5,54, \mathrm{KTK} 25,72 \mathrm{cmol} / \mathrm{kg}$ tanah dan KB 34,39\% Gambar 8. $\mathrm{mm}$. Untuk tipe iklim,berdasarkan sistem klasifikasi menurut Oldeman maka daerah 
Tabel 7. Hasil Analisis Contoh Tanah dilaboratorium Pengamatan Tanah dan Medan

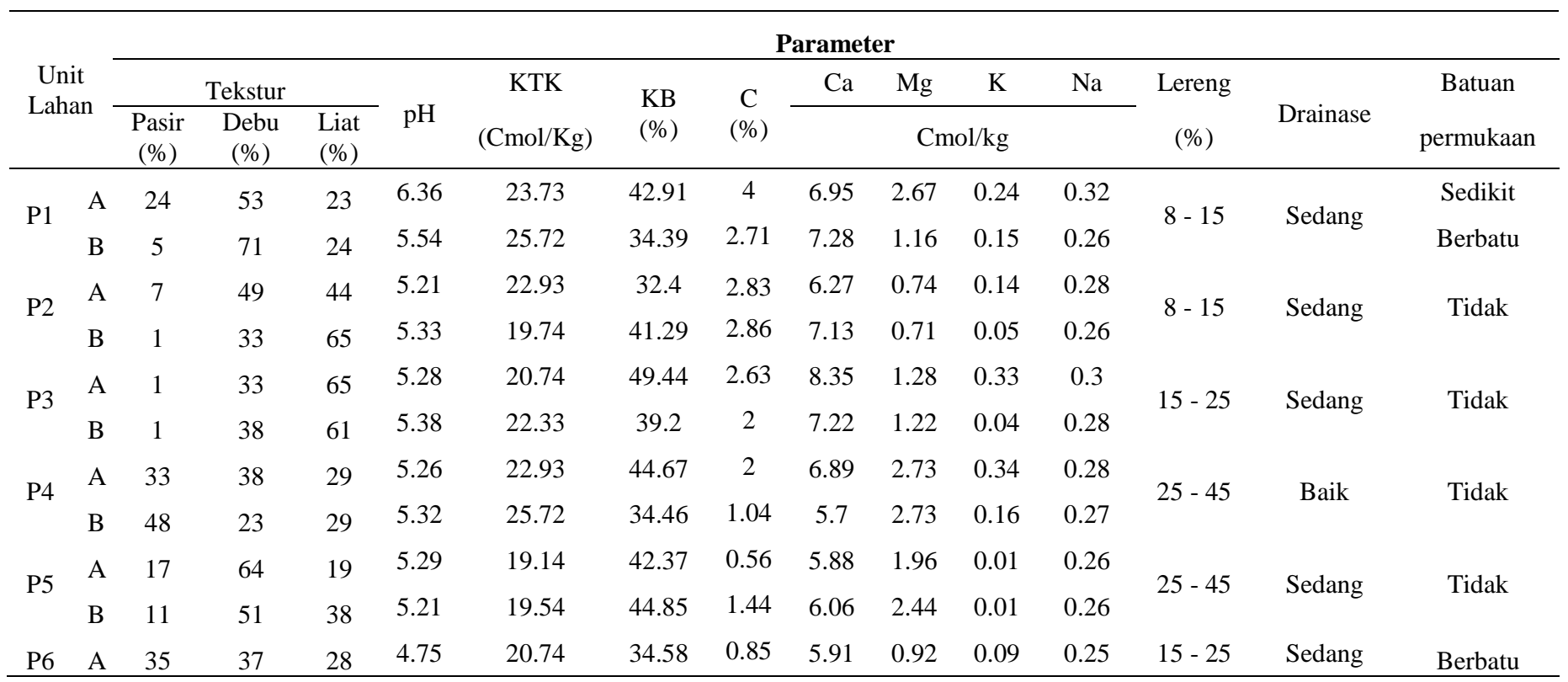

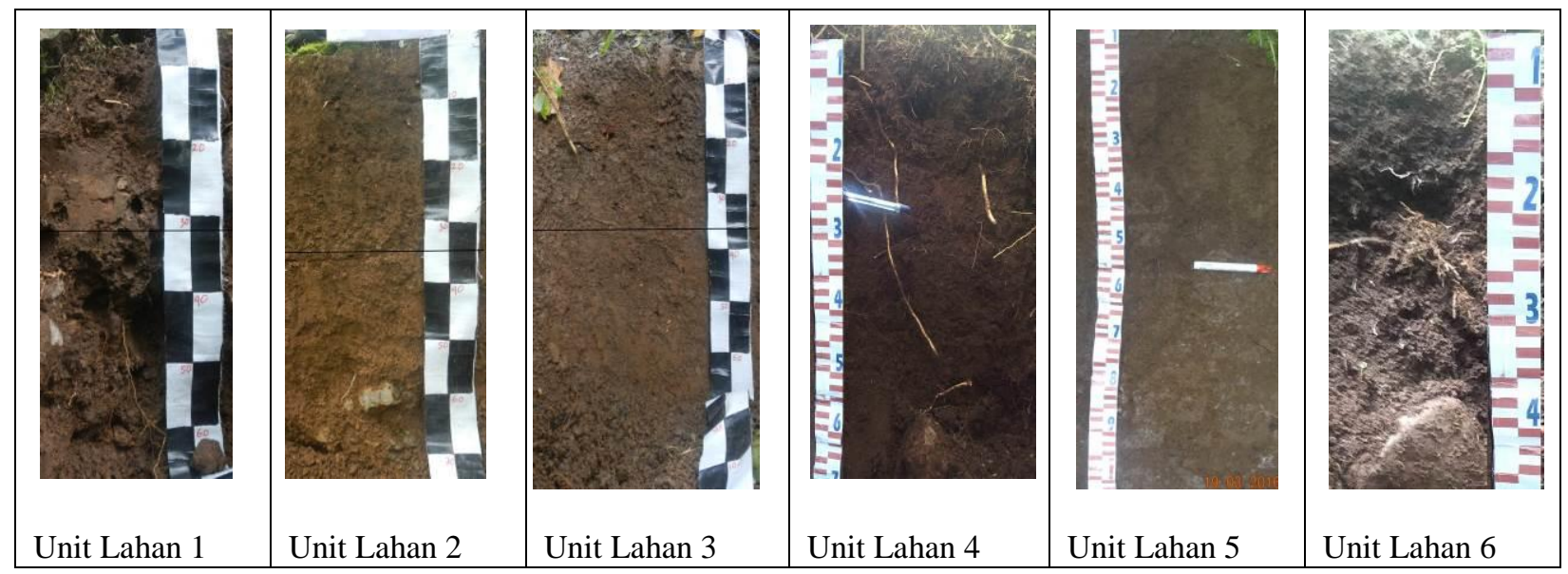

Gambar 8. Profil tanah pada unit lahan 1 hingga unit lahan 6

\section{Unit lahan 2}

Unit lahan 2 terletak pada koordinat $120^{\circ} 3^{\prime}$ 51.64" BT dan 5 28' 20.58" LS di Desa Borongkapala pada ketinggian \pm 357 mdpl. Topografi berombak (8-15\%), vegetasi didominasi kakao, kopi, gamal, dan pisang. Tidak ditemui adanya batuan diatas permukaan, dan tidak terlihat adanya erosi maupun genangan.
Hasil analisis laboratorium menunjukan pada horison A memiliki tekstur liat berdebu dengan kandungan pasir 7\%, debu $49 \%$ dan liat $44 \%$. Kandungan Corganik $2 \%, \mathrm{pH} 5,21, \mathrm{KTK} 22,93 \mathrm{cmol} / \mathrm{kg}$ tanah dan KB 32,4\%. Horison B memiliki tekstur liat dengan kandungan pasir $1 \%$, debu $33 \%$ dan liat $65 \%$. Kandungan C-organik $1,6 \%, \mathrm{pH} 5,33, \mathrm{KTK} 19,74 \mathrm{cmol} / \mathrm{kg}$ tanah dan KB 41,29\% (Gambar 8). 


\section{Unit lahan 3}

Unit lahan 3 terletak pada koordinat $120^{\circ} 2^{\prime}$ 36.34" BT dan 5 $5^{\circ}$ 26' 58.34" LS di Desa Banyorang pada ketinggian \pm 461 mdpl. Topografi agak terjal (15-25\%), vegetasi didominasi rambutan, durian, cengkeh, dan pisang. Tidak ditemui adanya batuan diatas permukaan, dan tidak terlihat adanya erosi maupun genangan.

Hasil analisis laboratorium menunjukan pada horison A memiliki tekstur liat dengan kandungan pasir $1 \%$, debu $33 \%$ dan liat $66 \%$. Kandungan C-organik $4,5 \%$, pH 5,28, KTK 20,74cmol/kg tanah dan KB 49,44\%. Horison B memiliki tekstur liat dengan kandungan pasir $1 \%$, debu $38 \%$ dan liat $61 \%$. Kandungan C-organik 12,5\%, pH 5,38 , KTK $22,33 \mathrm{cmol} / \mathrm{kg}$ tanah dan KB $39,2 \%$ (Gambar 8).

\section{Unit lahan 4}

Unit lahan 4 terletak pada koordinat $120^{\circ} 1^{\prime}$ 7.61" BT dan 5 5 $^{\circ} 4^{\prime} 43.70 "$ LS di Desa Labbo pada ketinggian \pm 644 mdpl. Topografi terjal (25-45\%), vegetasi didominasi jagung, langsat, dan pisang. Tidak ditemui adanya batuan diatas permukaan, dan tidak terlihat adanya genangan sedangkan bahaya erosi sedang.

Hasil analisis laboratorium menunjukan pada horison A memiliki tekstur lempung berliat dengan kandungan pasir $33 \%$, debu $38 \%$ dan liat $29 \%$. Kandungan Corganik 12,5\%, pH 5,26, KTK 22,93 cmol/kg tanah dan $\mathrm{KB} 44,67 \%$. Horison B memiliki tekstur lempung liat berpasir dengan kandungan pasir $48 \%$, debu $23 \%$ dan liat $29 \%$. Kandungan C-organik 24,5\%, pH 5,32, KTK $25,72 \mathrm{cmol} / \mathrm{kg}$ tanah dan KB $34,46 \%$ (Gambar 8).

\section{Unit lahan 5}

Unit lahan 5 terletak pada koordinat $120^{\circ} 0^{\prime}$ 33.08" BT dan 5० 23' 36.27" LS di Dusun
Bunung Kelurahan Pattaneteang pada ketinggian \pm 780 mdpl. Topografi terjal (25$45 \%$ ), vegetasi didominasi lada, gamal, kakao dan cengkeh. Tidak ditemui adanya batuan diatas permukaan, dan tidak terlihat adanya genangan sedangkan bahaya erosi ringan.

Hasil analisis laboratorium menunjukan pada horison A memiliki tekstur lempung berdebu dengan kandungan pasir $17 \%$, debu $64 \%$ dan liat $19 \%$. Kandungan Corganik 30,5\%, pH 5,29, KTK 19,14cmol/kg tanah dan KB 42,37\%. Horison B memiliki tekstur lempung liat berdebu dengan kandungan pasir $11 \%$, debu $51 \%$ dan liat $38 \%$. Kandungan C-organik 19,5\%, pH 5,21, KTK $19,54 \mathrm{cmol} / \mathrm{kg}$ tanah dan KB $44,85 \%$ (Gambar 8).

\section{Unit lahan 6}

Unit lahan 6 terletak pada koordinat $120^{\circ} 1^{\prime}$ 8.80" BT dan 5 ${ }^{\circ} 26^{\prime} 37.96 "$ LS di dusun Balumbung pada ketinggian \pm 619 mdpl. Topografi agak terjal (15-25\%), vegetasi didominasi lada, rambutan, kakao dan cengkeh. Ditemui adanya batuan diatas permukaan, dan tidak terlihat adanya genangan sedangkan bahaya erosi ringan.

Hasil analisis laboratorium menunjukan pada horison A memiliki tekstur lempung berliat dengan kandungan pasir $35 \%$, debu $37 \%$ dan liat $28 \%$. Kandungan Corganik 27\%, pH 4,75, KTK 20,74cmol/kg tanah dan KB 34,58\% (Gambar 8).

\section{Analisis Kesesuaian Lahan}

Hasil perbandingan (Matching) antara kriteria atau syarat tumbuh tanaman lada dengan data lapangan serta hasil analisis laboratorium dengan metode faktor pembatas sederhana yaitu setiap sifat-sifat lahan atau kualitas lahan disusun berurutan mulai dari yang terbaik (yang memiliki pembatas yang paling rendah) hingga yang terburuk atau yang terbesar penghambatnya. Masing- 
masing kelas disusun tabel kriteria untuk penggunaan tertentu demikian rupa, sehingga faktor pembatas terkecil untuk kelas terbaik dan faktor pembatas terbesar jatuh ke kelas terburuk maka diperoleh kelas kesesuaian lahan aktual dan potensial tanaman lada.

\section{Kelas Kesesuaian Lahan Aktual}

Kelas kesesuaian lahan aktual merupakan kesesuaian lahan berdasarkan data sifat biofisik tanah atau sumber daya lahan sebelum lahan tersebut diberikan masukan masukan yang diperlukan untuk mengatasi kendala. Data biofisik tersebut berupa karakteristik tanah dan iklim yang berhubungan dengan persyaratan tumbuh tanaman yang dievaluasi. Kelas kesesuaian lahan aktual tanaman lada di Kecamatan Tompobulu Kabupaten Bantaeng dapat dilihat pada Tabel 8 dan Gambar 9 adapun distribusi kelas kesesuaian lahan potensial dengan luasan dapat dilihat pada Tabel 9.

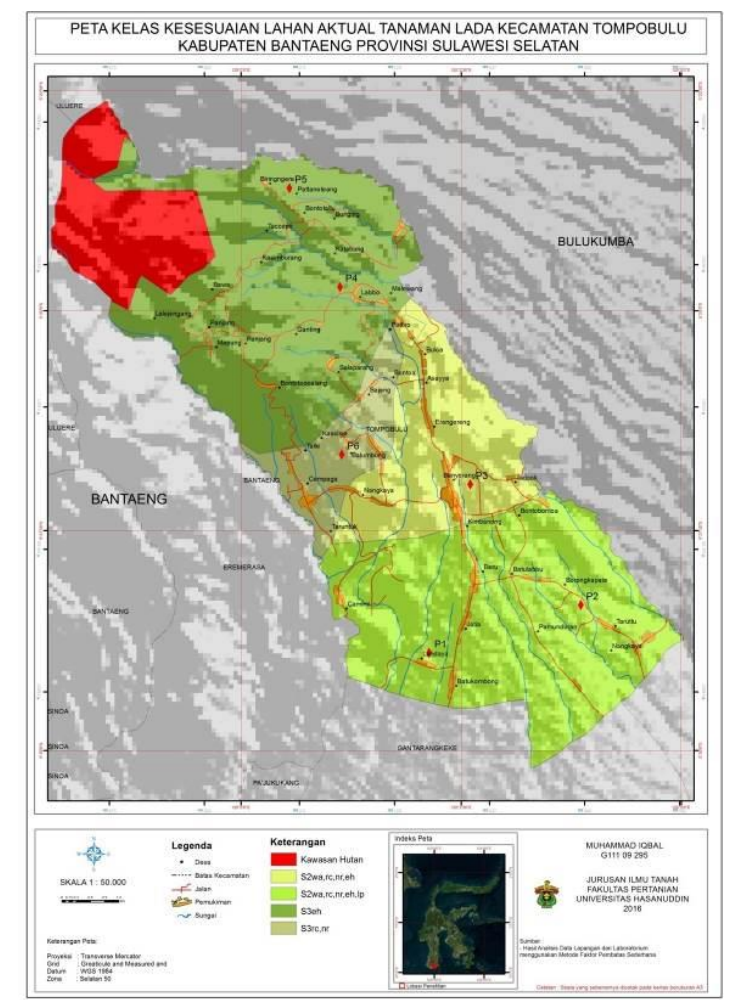

Gambar 9. Peta Kelas Kesesuaian Lahan Aktual Tanaman Lada
Tabel 8. Kelas Kesesuaian Lahan Aktual Tanaman Lada

\begin{tabular}{|c|c|c|c|c|c|c|}
\hline \multirow{3}{*}{$\begin{array}{c}\text { Persyaratan } \\
\text { Penggunaan/ } \\
\text { Karakteristik } \\
\text { Lahan } \\
\end{array}$} & \multicolumn{6}{|c|}{ Titik Profil dan Kelas Kesesuaian Lahan } \\
\hline & \multicolumn{6}{|c|}{ Unit Lahan } \\
\hline & 1 & 2 & 3 & 4 & 5 & 6 \\
\hline \multicolumn{7}{|l|}{ Temperatur (tc) } \\
\hline \multicolumn{6}{|l|}{$\begin{array}{l}\text { Ketersediaan air } \\
\text { (wa) }\end{array}$} & S1 \\
\hline $\begin{array}{l}\text { Curah hujan } \\
(\mathrm{mm})\end{array}$ & S2 & S2 & $\mathbf{S 2}$ & $\mathrm{S} 2$ & S2 & $\mathrm{S} 2$ \\
\hline $\begin{array}{l}\text { Kelembaban } \\
\text { udara }(\%)\end{array}$ & $\mathrm{S} 1$ & S1 & $\mathrm{S} 1$ & $\mathrm{~S} 1$ & S1 & S1 \\
\hline \multicolumn{7}{|l|}{$\begin{array}{l}\text { Ketersediaan } \\
\text { oksigen (oa) }\end{array}$} \\
\hline Drainase & $\mathrm{S} 1$ & S1 & S1 & $\mathrm{S} 1$ & $\mathrm{~S} 1$ & S1 \\
\hline \multicolumn{7}{|l|}{$\begin{array}{l}\text { Media perakaran } \\
\text { (rc) }\end{array}$} \\
\hline Tekstur & S1 & S1 & S1 & $\mathrm{S} 1$ & $\mathrm{~S} 1$ & S1 \\
\hline Bahan kasar (\%) & S1 & S1 & S1 & $\mathrm{S} 1$ & S1 & S1 \\
\hline $\begin{array}{l}\text { Kedalaman tanah } \\
(\mathrm{cm})\end{array}$ & S2 & S2 & S2 & $\mathrm{S} 2$ & $\mathrm{~S} 1$ & $\mathbf{S 3}$ \\
\hline \multicolumn{7}{|l|}{ Retensi hara (nr) } \\
\hline KTK liat (cmol) & $\mathrm{S} 1$ & S1 & S1 & $\mathrm{S} 1$ & $\mathrm{~S} 1$ & S1 \\
\hline $\begin{array}{l}\text { Kejenuhan basa } \\
(\%)\end{array}$ & S2 & $\mathbf{S 2}$ & S2 & $\mathrm{S} 2$ & $\mathrm{~S} 2$ & $\mathbf{S 3}$ \\
\hline pH H2O & $\mathrm{S} 1$ & S1 & S1 & $\mathrm{S} 1$ & S1 & S2 \\
\hline C-organik (\%) & $\mathrm{S} 1$ & $\mathrm{~S} 1$ & $\mathrm{~S} 1$ & $\mathrm{~S} 1$ & $\mathrm{~S} 1$ & $\mathrm{~S} 1$ \\
\hline \multicolumn{7}{|l|}{ Bahaya erosi (eh) } \\
\hline Lereng $(\%)$ & S2 & S2 & S2 & $\mathbf{S 3}$ & S3 & $\mathrm{S} 2$ \\
\hline Bahaya erosi & S1 & S1 & $\mathrm{S} 1$ & $\mathrm{~S} 1$ & $\mathrm{~S} 1$ & S1 \\
\hline \multicolumn{7}{|l|}{$\begin{array}{l}\text { Bahaya banjir } \\
\text { (fh) }\end{array}$} \\
\hline Genangan & $\mathrm{S} 1$ & $\mathrm{~S} 1$ & $\mathrm{~S} 1$ & $\mathrm{~S} 1$ & $\mathrm{~S} 1$ & $\mathrm{~S} 1$ \\
\hline \multicolumn{7}{|l|}{$\begin{array}{l}\text { Penyiapan lahan } \\
\text { (lp) }\end{array}$} \\
\hline $\begin{array}{l}\text { Batuan di } \\
\text { permukaan (\%) }\end{array}$ & S2 & S1 & S1 & $\mathrm{S} 1$ & S1 & S2 \\
\hline $\begin{array}{l}\text { Singkapan batuan } \\
(\%)\end{array}$ & $\mathrm{S} 1$ & $\mathrm{~S} 1$ & S1 & $\mathrm{S} 1$ & S1 & $\mathrm{S} 1$ \\
\hline Kelas Lahan & $\begin{array}{l}\text { S2wa,r } \\
\text { c, } \\
\text { nr,eh,lf }\end{array}$ & $\begin{array}{l}\mathrm{S} 2 \mathrm{w} \\
\mathrm{a}, \mathrm{rc}, \\
\mathrm{nr}, \mathrm{eh}\end{array}$ & $\begin{array}{l}\text { S2w } \\
\text { a,rc, } \\
\text { nr,eh }\end{array}$ & $\begin{array}{l}\text { S3 } \\
\text { eh }\end{array}$ & S3eh & $\begin{array}{c}\text { S3rc, } \\
\text { nr }\end{array}$ \\
\hline
\end{tabular}


Tabel 9. Distribusi Kelas Kesesuaian Lahan Aktual

\begin{tabular}{lcc}
\hline $\begin{array}{c}\text { Kelas Kesesuaian } \\
\text { Lahan Aktual }\end{array}$ & Luas (Ha) & $\begin{array}{c}\text { Persentase } \\
(\%)\end{array}$ \\
\hline S2wa,rc,nr,eh,lf & 2520.6 & 33.72 \\
S2wa,rc,nr,eh & 1136.4 & 15.20 \\
S3eh & 2503.3 & 33.48 \\
S3rc,nr & 520.1 & 6.96 \\
Kawasan Hutan & 795.6 & 10.64 \\
\hline Total & 7476 & 100 \\
\hline
\end{tabular}

\section{Kelas Kesesuaian Lahan Potensial}

Kelas kesesuaian lahan potensial menggambarkan kesesuaian lahan yang akan dicapai apabila dilakukan usaha usaha perbaikan lahan. Lahan yang dievaluasi dapat berupa hutan konversi, lahan terlantar, atau tidak produktif, atau lahan pertanian yang produktivitasnya kurang memuaskan tetapi masih memungkinkan untuk dapat di tingkatkan. Kelas kesesuaian lahan potensial tanaman lada di Kecamatan Tompobulu Kabupaten Bantaeng dapat dilihat pada Tabel 10 dan Gambar 10, adapun distribusi kelas kesesuaian lahan potensial dengan luasan dapat dilihat pada Tabel 11.

Tabel 10. Distribusi Kelas Kesesuaian Lahan Potensial

\begin{tabular}{lcc}
\hline $\begin{array}{c}\text { Kelas Kesesuaian } \\
\text { Lahan Potensial }\end{array}$ & Luas (Ha) & $\begin{array}{c}\text { Persentase } \\
(\%)\end{array}$ \\
\hline S2wa,rc & 6160.3 & 82.40 \\
S3rc & 520.1 & 6.96 \\
Kawasan Hutan & 795.6 & 10.64 \\
\hline Total & 7476 & 100 \\
\hline
\end{tabular}

Tabel 11. Kelas Kesesuaian Lahan Potensial Tanaman Lada setelah dilakukan perbaikan

\begin{tabular}{|c|c|c|c|c|c|c|}
\hline \multirow{3}{*}{$\begin{array}{c}\text { Persyaratan Penggunaan/ } \\
\text { Karakteristik Lahan }\end{array}$} & \multicolumn{6}{|c|}{ Titik Profil dan Kelas Kesesuaian Lahan } \\
\hline & \multicolumn{6}{|c|}{ Unit Lahan } \\
\hline & $\mathbf{1}$ & 2 & 3 & 4 & 5 & 6 \\
\hline \multicolumn{7}{|l|}{ Temperatur (tc) } \\
\hline $\begin{array}{l}\text { Temperatur rerata } \\
\left({ }^{\circ} \mathrm{C}\right) \text { harian }\end{array}$ & S1 & S1 & $\mathrm{S} 1$ & S1 & S1 & S1 \\
\hline \multicolumn{7}{|l|}{ Ketersediaan air (wa) } \\
\hline Curah hujan (mm) & S2 & S2 & $\mathbf{S 2}$ & S2 & S2 & S2 \\
\hline $\begin{array}{l}\text { Kelembaban udara } \\
(\%)\end{array}$ & S1 & $\mathrm{S} 1$ & $\mathrm{~S} 1$ & S1 & S1 & S1 \\
\hline \multicolumn{7}{|l|}{$\begin{array}{l}\text { Ketersediaan oksigen } \\
\text { (oa) }\end{array}$} \\
\hline Drainase & S1 & $\mathrm{S} 1$ & $\mathrm{~S} 1$ & S1 & S1 & S1 \\
\hline \multicolumn{7}{|l|}{ Media perakaran (rc) } \\
\hline Tekstur & S1 & $\mathrm{S} 1$ & $\mathrm{~S} 1$ & S1 & S1 & S1 \\
\hline Bahan kasar (\%) & S1 & S1 & S1 & S1 & S1 & S1 \\
\hline $\begin{array}{l}\text { Kedalaman tanah } \\
(\mathrm{cm})\end{array}$ & S2 & S2 & S2 & S2 & S1 & $\mathbf{S 3}$ \\
\hline \multicolumn{7}{|l|}{ Retensi hara (nr) } \\
\hline KTK liat (cmol) & S1 & S1 & $\mathrm{S} 1$ & S1 & S1 & S1 \\
\hline Kejenuhan basa (\%) & S1 & $\mathrm{S} 1$ & $\mathrm{~S} 1$ & S1 & S1 & S2 \\
\hline pH H2O & S1 & $\mathrm{S} 1$ & $\mathrm{~S} 1$ & S1 & S1 & S1 \\
\hline C-organik (\%) & S1 & $\mathrm{S} 1$ & $\mathrm{~S} 1$ & S1 & S1 & S1 \\
\hline \multicolumn{7}{|l|}{ Bahaya erosi (eh) } \\
\hline Lereng (\%) & S1 & $\mathrm{S} 1$ & $\mathrm{~S} 1$ & S2 & S2 & S1 \\
\hline Bahaya erosi & S1 & $\mathrm{S} 1$ & S1 & S1 & S1 & S1 \\
\hline \multicolumn{7}{|l|}{ Bahaya banjir (fh) } \\
\hline Genangan & S1 & $\mathrm{S} 1$ & $\mathrm{~S} 1$ & S1 & S1 & S1 \\
\hline \multicolumn{7}{|l|}{ Penyiapan lahan (lp) } \\
\hline $\begin{array}{l}\text { Batuan di permukaan } \\
(\%)\end{array}$ & $\mathrm{S} 1$ & $\mathrm{~S} 1$ & $\mathrm{~S} 1$ & S1 & S1 & S1 \\
\hline $\begin{array}{l}\text { Singkapan batuan } \\
(\%)\end{array}$ & S1 & $\mathrm{S} 1$ & $\mathrm{~S} 1$ & S1 & $\mathrm{S} 1$ & S1 \\
\hline Kelas Lahan & $\begin{array}{l}\text { S2wa, } \\
\text { rc }\end{array}$ & $\begin{array}{c}\mathrm{S} 2 \mathrm{w} \\
\mathrm{a}, \\
\mathrm{rc}\end{array}$ & $\begin{array}{c}\mathrm{S} 2 \mathrm{w} \\
\mathrm{a}, \\
\mathrm{rc}\end{array}$ & $\begin{array}{l}\text { S2wa, } \\
\text { rc }\end{array}$ & $\begin{array}{c}\text { S2wa, } \\
\text { rc }\end{array}$ & $\mathrm{S} 3 \mathrm{rc}$ \\
\hline
\end{tabular}




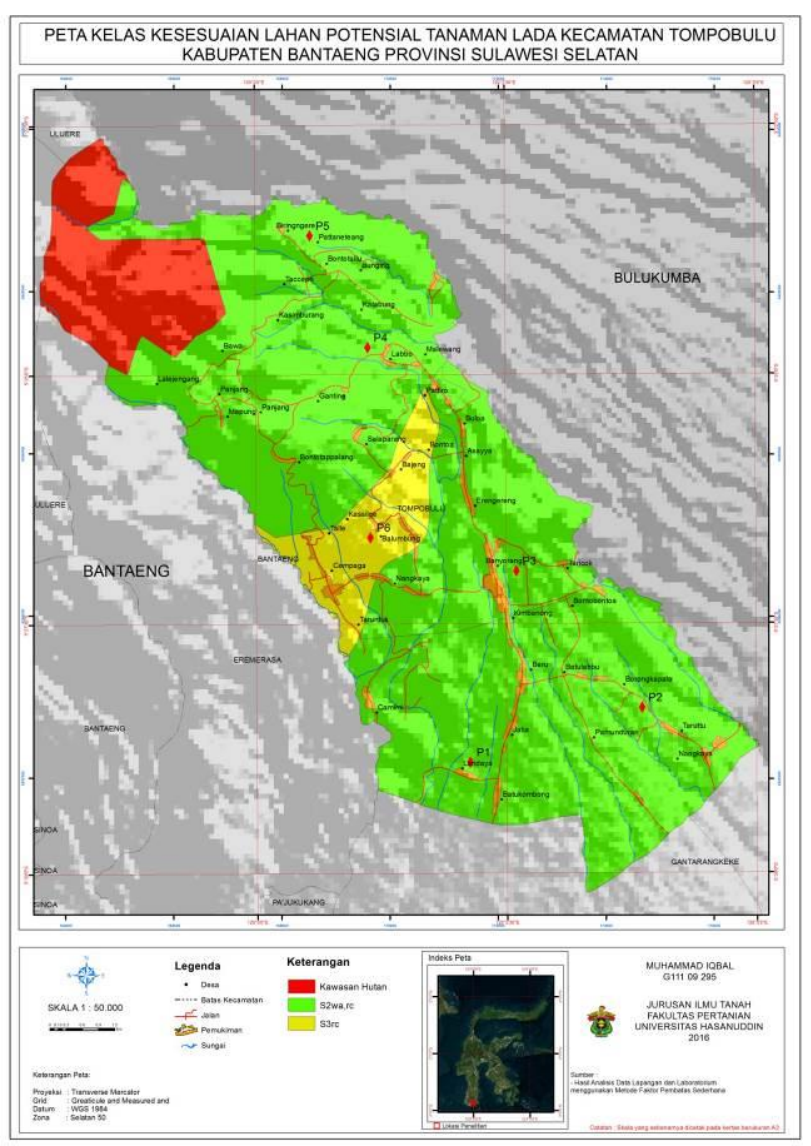

Gambar 10. Peta Kelas Kesesuaian Lahan Potensial Tanaman Lada Kecamatan Tompobulu Kabupaten Bantaeng Provinsi Sulawesi Selatan.

Berdasarkan hasil data Tabel 8 maka diperoleh kelas kesesuaian lahan aktual untuk tanaman lada dan Tabel 11 diperoleh kelas kesesuaian tanaman lada potensial setelah dilakukan perbaikan. Rangkuman penetapan tindakan perbaikan ditunjukan pada Tabel 12 . Kelas kesesuaian lahan aktual dan potensial tiap unit lahan sebagai berikut:

\section{Unit Lahan 1}

Pada unit lahan 1 diperoleh kelas kesesuaian lahan aktual S2wa,rc,nr,eh,lp yaitu lahan cukup sesuai. Faktor pembatas tersebut adalah curah hujan, kedalaman tanah, kejenuhan basah, lereng, dan batuan permukaan. Selanjutnya dengan dilakukan pengelolaan maka didapatkan kelas kesesuaian lahan potensial menjadi sangat sesuai (S1) untuk lereng dengan pembuatan teras, batuan permukaan yang tidak terlalu besar dan banyak pada lokasi ini dijadikan batas pada tiap teras dan meningkatkan kejenuhan basah berupa pemberian kapur bertujuan untuk meningkatkan $\mathrm{pH}$ tanah dari sangat masam atau masam ke $\mathrm{pH}$ agak netral atau netral, serta menurunkan kadar Al. Untuk menaikkan kadar $\mathrm{Ca}$ dan $\mathrm{Mg}$ dapat diberikan dolomit, walaupun pemberian kapur selain meningkatkan $\mathrm{pH}$ tanah juga dapat meningkatkan kadar $\mathrm{Ca}$ dan kejenuhan basa. Sedangkan faktor pembatas berupa curah hujan dan kedalaman tanah tidak dapat diperbaiki karena merupakan parameter bersifat permanen untuk jangka waktu yang cukup lama sehingga unit lahan 1 merupakan lahan cukup sesuai dengan faktor pembatas curah hujan dan kedalaman tanah atau S2wa,rc.

\section{Unit Lahan 2}

Pada unit lahan 2 diperoleh kelas kesesuaian lahan aktual S2wa,rc,nr,eh yaitu lahan cukup sesuai. Faktor pembatas tersebut adalah curah hujan, kedalaman tanah, kejenuhan basah dan lereng. Curah hujan dan kedalaman tanah tergolong komponen tidak bisa diperbaiki selanjutnya dengan dilakukan pengelolaan untuk lereng dengan pembuatan teras dan meningkatkan kejenuhan basa berupa pemberian kapur bertujuan untuk meningkatkan $\mathrm{pH}$ tanah dari sangat masam atau masam ke $\mathrm{pH}$ agak netral atau netral, serta menurunkan kadar Al. Untuk menaikkan kadar $\mathrm{Ca}$ dan $\mathrm{Mg}$ dapat diberikan dolomit, walaupun pemberian kapur selain meningkatkan $\mathrm{pH}$ tanah juga dapat meningkatkan kadar $\mathrm{Ca}$ dan kejenuhan basa. Sehingga unit lahan 2 merupakan lahan cukup sesuai dengan faktor pembatas curah hujan dan kedalaman tanah atau S2wa,rc. 


\section{Unit Lahan 3}

Pada unit lahan 3 diperoleh kelas kesesuaian lahan aktual S2wa,rc,nr,eh yaitu lahan cukup sesuai. Faktor pembatas tersebut adalah curah hujan, kedalaman tanah, kejenuhan basah dan lereng. Curah hujan dan kedalaman tanah tergolong komponen tidak bisa diperbaiki selanjutnya dengan dilakukan pengelolaan untuk lereng dengan pembuatan teras dan meningkatkan kejenuhan basa berupa pemberian kapur bertujuan untuk meningkatkan $\mathrm{pH}$ tanah dari sangat masam atau masam ke $\mathrm{pH}$ agak netral atau netral, serta menurunkan kadar Al. Untuk menaikkan kadar Ca dan Mg dapat diberikan dolomit, walaupun pemberian kapur selain meningkatkan $\mathrm{pH}$ tanah juga dapat meningkatkan kadar $\mathrm{Ca}$ dan kejenuhan basa. Sehingga unit lahan 3 merupakan lahan cukup sesuai dengan faktor pembatas curah hujan dan kedalaman tanah atau S2wa,rc.

\section{Unit Lahan 4 dan Unit Lahan 5}

Pada unit lahan 4 dan unit lahan 5 memiliki karakteristik lahan yang sama diperoleh kelas kesesuaian lahan aktual S3eh yaitu lahan sesuai marjinal. Faktor pembatas tersebut adalah lereng. Selanjutnya dengan dilakukan pengelolaan untuk lereng dengan teknik konservasi baik secara vegetatif maupun mekanik. Teknik vegetatif adalah suatu cara pengelolaan lahan miring dengan menggunakan tanaman sebagai sarana konservasi tanah (Seloliman, 1997). Tanaman penutup tanah ini selain untuk mencegah atau mengendalikan bahaya erosi juga dapat berfungsi memperbaiki struktur tanah, menambahkan bahan organik tanah, mencegah proses pencucian unsur hara dan mengurangi fluktuasi temperatur tanah sedangkan teknik mekanik berupa pengelolaan tanah menurut kontur atau pembuatan teras. Pengolahan tanah menurut kontur adalah setiap jenis pengolahan tanah (pembajakan, pencangkulan, pemerataan) mengikuti garis kontur sehingga terbentuk alur-alur dan jalur tumpukan tanah yang searah kontur dan memotong lereng sedangkan teras adalah bangunan konservasi tanah dan air secara mekanis yang dibuat untuk memperpendek panjang lereng dan atau memperkecil kemiringan lereng dengan jalan penggalian dan pengurugan tanah melintang lereng. Tujuan pembuatan teras adalah untuk mengurangi kecepatan aliran permukaan (run off) dan memperbesar peresapan air, sehingga kehilangan tanah berkurang(Sukartaatmadja,2004). Teras berfungsi mengurangi panjang lereng dan menahan air, sehingga mengurangi kecepatan dan jumlah aliran permukaan, dan memungkinkan penyerapan air oleh tanah. Dengan demikian erosi berkurang. (Arsyad, 1989) Sehingga unit lahan 4 dan unit lahan 5 merupakan lahan cukup sesuai dengan faktor pembatas curah hujan dan kedalaman tanah atau S2wa,rc.

\section{Unit Lahan 6}

Pada unit lahan 6 diperoleh kelas kesesuaian lahan aktual S3rc,nr yaitu lahan sesuai marjinal. Faktor pembatas tersebut adalah kedalaman tanah dan kejenuhan basah. Faktor pembatas kedalaman tanah tidak dapat diperbaiki karena merupakan parameter bersifat permanen untuk jangka waktu yang cukup lama dan butuh biaya yang cukup besar. Sedangkan faktor pembatas kejenuhan basa dapat dilakukan teknik pengapuran, Pemberian kapur bertujuan untuk meningkatkan $\mathrm{pH}$ tanah dari sangat masam atau masam ke $\mathrm{pH}$ agak netral atau netral, serta menurunkan kadar Al. Untuk menaikkan kadar $\mathrm{Ca}$ dan $\mathrm{Mg}$ dapat diberikan dolomit, walaupun pemberian kapur selain meningkatkan $\mathrm{pH}$ tanah juga dapat meningkatkan kadar $\mathrm{Ca}$ dan kejenuhan basa. Makin besar persentase kejenuhan Al dalam tanah, maka makin banyak kapur yang harus diberikan ke dalam tanah untuk mencapai $\mathrm{pH}$ agak netral sampai netral (Sumarni et al 
2010). sehingga unit lahan 6 merupakan lahan cukup sesuai dengan faktor pembatas curah hujan dan kedalaman tanah atau S3rc.

Kelas kesesuaian lahan aktual dan potensial lebih lanjut dapat dilihat pada peta kelas kesesuaian lahan tanaman lada aktual dan potensial pada lampiran.

Tabel 12. Tindakan perbaikan pembatas lahan

\begin{tabular}{|c|c|c|c|c|}
\hline $\begin{array}{c}\text { Unit } \\
\text { Lahan }\end{array}$ & $\begin{array}{c}\text { Kelas } \\
\text { Kesesuaian } \\
\text { Lahan } \\
\text { Aktual } \\
\end{array}$ & $\begin{array}{c}\text { Faktor } \\
\text { Pembatas }\end{array}$ & $\begin{array}{l}\text { Tindakan } \\
\text { Perbaikan }\end{array}$ & $\begin{array}{c}\text { Kelas } \\
\text { Kesesuaian } \\
\text { Lahan } \\
\text { Potensial }\end{array}$ \\
\hline 2 & $\begin{array}{c}\text { S2wa,rc, } \\
\text { nr,eh,lf }\end{array}$ & $\begin{array}{l}\text { curah hujan, } \\
\text { kedalaman } \\
\text { tanah, } \\
\text { kejenuhan basa, } \\
\text { lereng, dan } \\
\text { batuan } \\
\text { permukaan } \\
\text { curah hujan, } \\
\text { kedalaman } \\
\text { tanah, } \\
\text { kejenuhan basa } \\
\text { dan lereng }\end{array}$ & $\begin{array}{l}\text { pemberian } \\
\text { kapur, } \\
\text { dolomit dan } \\
\text { pembuatan } \\
\text { teras } \\
\text { pemberian } \\
\text { kapur, } \\
\text { dolomit dan } \\
\text { pembuatan } \\
\text { teras }\end{array}$ & S2wa,rc \\
\hline 3 & $\begin{array}{c}\text { S2wa,rc, } \\
\text { nr,eh }\end{array}$ & $\begin{array}{l}\text { curah hujan, } \\
\text { kedalaman } \\
\text { tanah, } \\
\text { kejenuhan basa } \\
\text { dan lereng }\end{array}$ & $\begin{array}{l}\text { pemberian } \\
\text { kapur, } \\
\text { dolomit dan } \\
\text { pembuatan } \\
\text { teras }\end{array}$ & S2wa,rc \\
\hline 4 & S3eh & lereng & $\begin{array}{l}\text { pembuatan } \\
\text { teras }\end{array}$ & S2wa,rc \\
\hline 5 & S3eh & lereng & $\begin{array}{l}\text { pembuatan } \\
\text { teras }\end{array}$ & S2wa,rc \\
\hline 6 & S3rc,nr & $\begin{array}{l}\text { kedalaman } \\
\text { tanah dan } \\
\text { kejenuhan basa }\end{array}$ & $\begin{array}{l}\text { pemberian } \\
\text { kapur dan } \\
\text { dolomit }\end{array}$ & S3rc \\
\hline
\end{tabular}

\section{Produksi Tanaman Lada}

Produksi tanaman lada khususnya di Kecamatan Tompobulu Kabupaten Bantaeng pada tahun 2008 sebesar 10.25 ton, pada tahun 2011 mengalami peningkatan dengan produksi sebesar 11 ton namun menurun di tahun 2015 sebesar 9 ton(Dinas Perkebunan dan Hortikultura Kabupaten Bantaeng,2015).

Hasil interview (wawancara) dengan petani Lada di lokasi penelitian menunjukkan bahwa hasil Lada berkisar antara $50 \mathrm{~kg}$ hingga $75 \mathrm{~kg}$ tiap areal kebun petani. Hasil produksi berdasarkan interview (wawancara) tiap petani dapat dilihat pada Tabel 13.

Tabel 13. Data Produksi Tanaman Lada Petani

\begin{tabular}{llc}
\hline \multicolumn{1}{c}{ Nama } & \multicolumn{1}{c}{ Lokasi } & Produksi $(\mathbf{K g})$ \\
\hline Makka & Landaya & 67 \\
Dg. Baji & Borongkapala & 67 \\
Arifin & Banyorang & 72 \\
Dg. Rimang & Banyorang & 70 \\
Pak Imam & Balumbung & 61 \\
Syamsuddin & Labbo & 71 \\
Rabia' & Labbo & 50 \\
Dg. Kebo & Pattaneteang & 63 \\
Azis & Pattaneteang & 75 \\
Anjas & Taruttu & 70 \\
Sumber: hasil interview petani &
\end{tabular}

Berdasarkan data tersebut produksi tanaman lada di Kecamatan Tompobulu Kabupaten Bantaeng masih kurang disebabkan luas lahan yang dimiliki setiap petani masih kurang, setiap areal perkebunan masih menggunakan sistem tumpang sari yang didominasi tanaman lain yaitu Cengkeh, Kakao, Pisang, Nenas, jagung dan Gamal.

Jika dikaitkan dengan potensi hasil Lada yang dikelola dengan optimal bisa mencapai $2 \mathrm{~kg}$ per pohon yang berarti dapat menghasilkan 5 ton/ha, maka hasil yang diperoleh petani saat ini dengan sistem tumpangsari dan pemeliharaan yang tidak optimal di lokasi penelitian, maka hasilnya tidak menguntungkan untuk petani. Untuk itu, penelitian ini dapat menjadi dasar penetapan lokasi-lokasi yang potensial untuk pengembangan tanaman Lada di Kecamatan Tompobulu Kabupaten Bantaeng. 


\section{KESIMPULAN}

Kelas kesesuaian lahan aktual kecamatan tompobulu untuk tanaman lada tergolong S2 (cukup sesuai) dengan faktor pembatas curah hujan, kejenuhan basa, kelerengan, batuan permukaan seluas 3657 ha $(48,92 \%)$, S3 (sesuai marginal) dengan faktor pembatas kedalaman tanah, kejenuhan basah, kelerangan seluas 3023,4ha(40,44\%), Dan N (tidak sesuai) dengan luas lahan 795,6ha $(10,64 \%)$.

Kelas kesesuaian lahan potensial setelah dilakukan perbaikan dengan dilakukan pengelolaan untuk lereng dengan pembuatan teras dan meningkatkan kejenuhan basa berupa pemberian kapur dan dolomit yang kelas kesesuaiannya tergolong S2 yakni dengan luas lahan 6160ha $(82,40 \%)$, serta pengelolaan untuk lereng dengan teknik konservasi baik secara vegetatif maupun mekanik yang kelas kesesuaiannya tergolong S3 seluas 520,1 $(6,96 \%)$ dan $\mathrm{N}$ seluas 795,6ha (10,64\%) yang diperuntukkan untuk kawasan hutan.

\section{DAFTAR PUSTAKA}

AAK. 1993. Dasar-Dasar Bercocok Tanam. Yogyakarta: Kanisius

Arsyad, S. 1989. Konservasi Tanah dan Air. Bogor: Penerbit IPB Press

Bakosurtanal. 1989. Peta Reppprot (Land System) Lembar Kabupaten Bantaeng.

Bakosurtanal. 1991. Peta Rupa Bumi Indonesia no 2010-62.

Djaenudin, D., Marwan, H., Subagyo, H., Mulyani, A., dan Suharta, N. 2000.Kriteria Kesesuaian Lahan Untuk Komoditas Pertanian. Pusat Penelitian Tanah dan Agroklimat. Bogor.
Hardjowigeno, S. 2003. Ilmu Tanah. Akademika Pressindo. Jakarta.

Kartasapoetra. 1988. Pengantar Ilmu Tanah. Jakarta : PT. Bina Aksara.

Lopulisa, C., 2001, Evaluasi Kesesuaian Lahan. Bahan Mata Kuliah Program Studi Sistem Sistem Pertanian. Pasca Sarjana Universitas Hasanuddin. Makassar.

Lopulisa, C. Husni, H. 2011, Evaluasi Lahan. Lembaga Penelitian dan Pengabdian Masyarakat. Universitas Hasanuddin. Makassar.

Nasution, Z., 2005. Evaluasi Lahan Daerah Tangkapan Hujan Danau Toba Sebagai Dasar Perencanaan Tata Guna Lahan untuk Pembangunan Berkelanjutan. USU. Medan.

Nurmas, A. 2010. HandOut Mata Kuliah Budidaya Tahunan. Komoditas Lada. JurusanAgroteknologi. Fakultas Pertanian. Universitas Haluoleo. Kendari.

Pairunan. A. K. dkk. 1985. Dasar-Dasar Ilmu Tanah. Ujung Pandang: BKPT. INTIM.

Ritung, S., Wahyunto, F. Agus, dan H. Hidayat. 2007. Panduan EvaluasiKesesuaian Lahan dengan Contoh Peta Arahan PenggunaanUniversitas Sumatera UtaraLahan Kabupaten Aceh Barat. Balai Penelitian Tanahdan World Agroforestry Centre (ICRAF). Bogor.

Sandy, 1977. Penggunaan Tanah (Land USE) di Indonesia Publikasi No 75.Jakarta : Direktorat tata Guna Tanah Dirjen Agraria Departemen dalam Negeri. 
Seloliman. 1997. Agroforestry for Upland Husbandry : a Farmers' Friendly. Presentasi Workshop Agroforestry 2004, Fakultas Kehutanan, Universitas Gadjah Mada, Yogyakarta

Sitorus.1995. Evaluasi Kesesuaian Lahan.Tarsito. Bandung

Sitorus. 2004. Evaluasi Sumberdaya Lahan. Tarsito. Bandung

Sitorus, MT Felix. 1998. Penelitian Kualitatif: Suatu Perkenalan. Bogor:Kelompok Dokumentasi Ilmuilmu Sosial.

Sukartaatmadja.2004. Konservasi Tanah dan Air. IPB Press. Bogor

Sumarni, N, Rosliani, R. dan Duriat, A.S. 2010. Pengelolaan Fisik, Kimia, dan Biologi Tanah untuk Meningkatkan Kesuburan Lahan dan Hasil Cabai Merah. J. .Hort 21 (4):130-137

Sys, C., E. Van Ranst, J. Debaveye. 1991. Land Evaluation. CropRequirements Part I. Agricultural Publication No. 7. General Administration for Development Corp. 1050 BrusselsBelgium.

Wahid, P. dan U Suparman. 1986. Teknik Budidaya untuk Meningkatkan Produktivitas Tanaman Lada. Edisi Khusus Littro Vol II No. 1 Balai Penelitian Tanaman Rempah dan Obat 